\title{
INVESTIGATION OF MORAL SENSITIVITY IN NURSES
}

\author{
Samineh Esmailzadeh ${ }^{1 *}$ \\ Özdem Nurluöz ${ }^{2}$ \\ Emine Çakırcalı ${ }^{3}$
}

\begin{abstract}
Nurses should have an advanced moral sensitivity, which is defined as the ability to distinguish ethical problem, in order to make the right decision regarding the identification and analysis of ethical problems.Each nurse may have different perspective on ethical problems and solution approach respectively. Moral sensitivity level in nurses is a major factor in such variation. Hence, the analysis on moral sensitivity among nurses and identification of different variables affecting their moral sensitivity are crucial. This study aims to measure the moral and ethical sensitivity of hospital nurses towards the patients and other staff. The sample of this study, which was planned as descriptive and cross-sectional, is the voluntary nurses from two training hospitals $(n=600)$. Introductory information form and

Moral Sensitivity Scale were both used in data collection. The research data was analysed with Statistical Package for Social Sciences (SPSS) 24.0. Frequency analysis was utilised for the distribution of socio-demographic characteristics; the comparison of data set with normal distribution was analysed with Kolmogorov-Smirnov test and MannWhitney $\mathrm{U}$ test and Kruskal-Wallis $\mathrm{H}$ test - non-parametric hypothesis tests were conducted as data found not compatible with normal distribution. In consideration with results, majority of nurses encounter with ethical problems at their departments. While $50.86 \%$ of nurses overcome such problems, around $20 \%$ of them are not able to solve their problems accordingly. Conclusion: The findings reflected that the moral sensitivity levels among nurses positively differ with their professional
\end{abstract}

\footnotetext{
${ }^{1}$ Near East University. Turkish Republic of Northern Cyprus, http://orcid.org/0000-0001-7390-499X, samineh_khalilazar@yahoo.com

${ }^{2}$ Near East University. Turkish Republic of Northern Cyprus, http://orcid.org/0000-0002-3697-2712, ozdem.nurluoz@neu.edu.tr

${ }^{3}$ Near East University. Turkish Republic of Northern Cyprus, emine.cakircali@neu.edu.tr, https://orcid.org/0000-0001-9797-0596
} 
seniority and way of work whereas some factors negatively affect the moral sensitivity levels.

Keywords:Ethics, Sensitivity, Moral Sensitivity, Nursing and Ethics, Ethical Behaviour.

\section{INTRODUCTION}

Global changes and developments in patient care influence nursing practices and based on the circumstances at workspace, there is an increasing need for ethics (Özcan M, Akpinar A, Ergin AB.2012).

Pursuant to Çobanoğlu(2004), ethics is defined as a sub-branch of philosophy and a systematic thinking activity where human behaviours are evaluated as good-bad. Ethics is a philosophy discipline presenting verifiable or non-verifiable information on human ethical problems or at least expected to present rather than an activity telling what to do or imposing norms.

Aydın İp(2012) defined the concept of ethics in the way of analysing good and bad behaviours. In other words, ethics is the whole moralities that comprise the basis of individual behaviours. Ethical dilemma is a conflict between two values in the circumstances where a judgment should be made during an act (Redman BK, Fry S. Nurses 2000). In everyday life, many ethical dilemmas occur and their associated decisions have vital effects on the society, which indicate the necessity for the availability of healthcare provision with advanced moral sensitivity and ethical values. Pursuant to Kim YS, Park JW, Son YJ. A(2004), ethical values reflect our acknowledgements that comprise objects, individuals, thoughts, circumstances and actions as right, wrong, wanted, unwanted etc. Values are explained as our affirmations that establish our judgments of right, wrong, wanted, unwanted and etc. on items, thoughts, circumstances and actions(Halstead J. Taylor MJ. E. 2000). Moral sensitivity is the awareness of ethical values or roles and responsibilities of individual in an existing situation where difference of opinions exists (Pekcan, H.S, 2007; Tosun, H, 2005; Öztürk H, Hintistan S, Kasım S andCandaş, B,2009).

In accordance with Tosun, $\mathrm{H}$; 2005 andÖztürk H, Hintistan S, Kasım S andCandaş, B, (2009), moral sensitivity is explained as solving ethical problems in all healthcare departments, clarifying 
problems, legitimising problems and performed action or preventing and showing sensitivity towards an ethical dilemma; whereas Pekcan(2007) defended that nurses should have an advanced level of ability to identify ethical problems and analyse problems, distinguish an existing ethical problem together with a high level of moral sensitivity so that they can make right decisions accordingly.

Lützén K, Blom T, EwaldsKvist B, Winch S. (2010) emphasized that in the performance of tasks, nurses may cause many problems within the scope of ethical thinking, acting and their responsibilities. In consideration with the area of responsibility in the profession, employees underline the significance of ethical decision making based on the available contradicting values. There are many interwoven professions within nursing, which shows the necessity of ethical values in the profession (Jahantigh M, Arbabisarjou A, Zare S, Shahrakipour M, Ghoreishinia G 2015, Miandoab NY, Arbabisarjou A, Zare S, Shahrakipour M, Bradang N, 2015).Considering the medical factors, technological developments, resource allocation, inevitable increase in expenditures, increase in elderly population and individual rights in such profession, the changes in the roles of nurses may cause ethical conflicts (Schroeter, K. 1999).

Nurses encounter with various challenges while providing care to the patients in their related departments, and they have a major role in satisfying patients with regard to treatment services(Salar, A.,Zare., S., Sharifzadeh, E, 2016).

Different approaches between other team members and institution regarding patient care and treatment, protection of patient rights, care of terminal patients, acquisition of informed consent, allocation of limited resources and unethical attitudes of colleagues are listed as the most common ethical problems faced by nurses(Pekcan H. S., 2007). In order to solve ethical problems, it is particularly important to know ethical problems, embrace them as problems and make the right decision in case of its realization.

Fry S. (2000) indicated that professional ethics course, which student nurses take during their education, aims to guide students in acting responsibly and making ethical decisions based on ethical values during their future performances. 
Privacy is an essential individual right (O'Keefe, 2001), which is related with confidentiality. Privacy means to control the disclosure of individual body or personal information or secrecy and have the right to protect such rights respectively.

Considering that there is limited number of studies analysing the moral sensitivity of emergency nurses (Sar1, D. et.al. 2017) as well as covering emergency services with regard to moral sensitivity, it is necessary to develop institutional policies towards solving ethical problems, and to improve work conditions.

\section{AIM}

Each nurse may have different perspective and solutions concerning ethical problems. The reason behind such difference is the moral sensitivity levels among nurses. Hence, the analysis of moral sensitivity among nurses and identification of variables affecting moral sensitivity are vital. This study was conducted to determine the ethical and moral sensitivities of nurses in decision-making process.

\section{MATERIAL AND}

\section{METHOD}

This study was developed as descriptive and cross-sectional in order to identify the moral sensitivity of hospital nurses.

The research questions are as follows:

- What are the moral sensitivity levels of nurses?

- Is there any relation between nurses' personal and professional characteristics and their moral sensitivity?

- Have nurses been taught any course on ethics during their education?

- Is there any relation between ethical and moral sensitivity of nurses working at the two large hospitals subject to the research?

\subsection{Research Population and Sample}

Upon the acquisition of consent from institution and ethics committee approval, the research population was comprised of nurses from a Training and Research Hospital and a State Hospital. All voluntary nurses were included into the research $(n=600,100 \%$ of population). The study was conducted between April - June 2018.

\subsection{Data Collection Tools}


GÊNERO E INTERDISCIPLINARIDADE
"Introductory Information Form" and "Moral Sensitivity Scale" were used in data collection.

Moral Sensitivity Scale, which was developed by Kim Lutzen to measure moral sensitivity(1994, Sweden, Stockholm), was firstly applied on nurses and doctors working at psychiatry clinic and then other departments. The scale, which consists of thirty items and six sub-dimensions (Autonomy, Benefit, Integrative Approach, Conflict, Application and Orientation), is a seven point Likert type of scale ranging between 1 (Strongly agree) and 7 (Strongly disagree). While ' 1 point' represents high sensitivity, '7 points' shows low sensitivity, the total score to be obtained from this scale varies between the scores of 30-210. High score shows morally low sensitivity, yet low score reflects morally high sensitivity.In Turkey, the scale validity and reliability was tested by Hale Tosun in 2003 with Cronbach Alpha value as 0.84 whereas the related value was found as 0.80 under the study byBaşaket.al.

\section{FINDINGS}

\subsection{Statistical Data Analysis}

The research data was analysed via Statistical PackageforSocialSciences (SPSS) 24.0 software. The sociodemographic distribution of nurses subject to the research was determined with frequency analysis and the descriptive statistics based on their scores from the Moral Sensitivity Scale were provided respectively.

Kolmogorov-Smirnov test was applied to check the conformity of data set with normal distribution in order to compare the scores obtained by nurses from the Moral Sensitivity Scale based on their socio-demographic characteristics, and the data set was found as incompatible with normal distribution. Therefore, Mann-Whitney U test and Kruskal-Wallis $\mathrm{H}$ test, both of which are non-parametric hypothesis tests, were conducted accordingly.

Among the nurses within the scope of this research, $36,36 \%$ are at the age of 30 and below; 39,39\% between the ages of $31-40$ and $24,24 \%$ at the age of 41 and above; 83,64\% are female and $67,27 \%$ are male; and $56,97 \%$ have bachelor's degree while $27,27 \%$ have postgraduate degree.

Moreover, $62,42 \%$ of nurses worked at state hospital while $37,58 \%$ at private hospital and $26,06 \&$ have a 5 - 
year and lessprofessional seniority, $24,24 \%$ have between 6-10-year and $49,70 \%$ have an 11-year and moreprofessional seniority; $41,21 \%$ worked at the hospital for 5 years and less, $24,85 \%$ for $6-10$ years and $33,94 \%$ for 11 years and more; $85,45 \%$ are clinic nurses, $22,42 \%$ have between $4-6$ night shifts monthly, 38,79\% have 7 and more night shift while $27,88 \%$ do not have at all. Among the related nurses;52,12\% had training on ethics; $70,30 \%$ had ethical problems in their departments and $50,86 \%$ of nurses with such problems solved the situation respectively.

Table 1. Scores of Nurses from Moral Sensitivity Scale

\begin{tabular}{lccccc}
\hline & $\mathrm{n}$ & $\bar{x}$ & $\mathrm{~s}$ & Min & Max \\
\hline Autonomy & 165 & 3,10 & 0,86 & 1 & 5,71 \\
Benefit & 165 & 3,42 & 0,97 & 1 & 6,00 \\
Integrated Approach & 165 & 2,45 & 0,70 & 1 & 4,80 \\
Conflict & 165 & 4,55 & 1,31 & 1 & 7,00 \\
Application & 165 & 3,80 & 1,41 & 1 & 6,25 \\
Orientation & 165 & 2,51 & 0,91 & 1 & 4,50 \\
Moral Sensitivity Scale & 165 & 3,31 & 0,72 & 1 & 4,90 \\
\hline
\end{tabular}

In consideration with Table 1, nurses $\operatorname{got} \bar{x}=3,31 \pm 0,72$ from the Moral Sensitivity Scale, $\bar{x}=3,10 \pm 0,86$ from the sub-dimension of autonomy, $\bar{x}=3,42 \pm 0,97$ from the sub-dimension of benefit, $\bar{x}=2,45 \pm 0,70$ from the sub- dimension of integrated approach, $\bar{x}=4,55 \pm 1,31$ from the sub-dimension of conflict, $\bar{x}=3,80 \pm 1,41$ from the subdimension of application and $\bar{x}=2,51 \pm 0,91$ from the sub-dimension of orientation.

Table 2. Comparison of Moral Sensitivity Scale Scores by the Type of Hospitals Where Nurses Work 
INTERDISCIPLINARIDADE

\begin{tabular}{|c|c|c|c|c|c|c|c|}
\hline & Type of Hospital & $\mathrm{n}$ & $\bar{x}$ & $\mathrm{~s}$ & SO & $\mathrm{Z}$ & $\mathrm{p}$ \\
\hline \multirow{2}{*}{ Autonomy } & Private & 62 & 2,83 & 0,92 & 67,71 & \multirow{2}{*}{$-3,204$} & \multirow{2}{*}{$0,001 *$} \\
\hline & State & 103 & 3,26 & 0,78 & 92,20 & & \\
\hline \multirow{2}{*}{ Benefit } & Private & 62 & 3,30 & 1,17 & 76,42 & \multirow{2}{*}{$-1,383$} & \multirow{2}{*}{0,167} \\
\hline & State & 103 & 3,50 & 0,83 & 86,96 & & \\
\hline \multirow{2}{*}{ Integrated Approach } & Private & 62 & 2,56 & 0,93 & 88,02 & \multirow{2}{*}{$-1,055$} & \multirow{2}{*}{0,291} \\
\hline & State & 103 & 2,38 & 0,51 & 79,98 & & \\
\hline \multirow{2}{*}{ Conflict } & Private & 62 & 4,63 & 1,54 & 86,94 & \multirow{2}{*}{$-0,827$} & \multirow{2}{*}{0,408} \\
\hline & State & 103 & 4,51 & 1,14 & 80,63 & & \\
\hline \multirow{2}{*}{ Application } & Private & 62 & 3,38 & 1,15 & 68,35 & \multirow{2}{*}{$-3,065$} & \multirow{2}{*}{$0,002 *$} \\
\hline & State & 103 & 4,05 & 1,50 & 91,82 & & \\
\hline \multirow{2}{*}{ Orientation } & Private & 62 & 2,31 & 1,04 & 72,46 & \multirow{2}{*}{$-2,214$} & \multirow{2}{*}{$0,027 *$} \\
\hline & State & 103 & 2,63 & 0,81 & 89,34 & & \\
\hline \multirow{2}{*}{ Moral Sensitivity Scale } & Private & 62 & 3,17 & 0,80 & 73,74 & \multirow{2}{*}{$-1,932$} & \multirow{2}{*}{0,053} \\
\hline & State & 103 & 3,39 & 0,66 & 88,57 & & \\
\hline
\end{tabular}

$*_{p}<0,05$

Table 2 presents the results from Mann-Whitney U test conducted with regard to the comparison of nurses' scores from the Moral Sensitivity Scale by the type of hospitals. The difference between the nurses' scores from the Moral Sensitivity Scale by the hospital that they work in general and the scores from the sub-dimensions of benefit, integrated approach and conflict is not statistically significant ( $\mathrm{p}>0,05)$.

The difference between the nurses' scores from the sub-dimensions of autonomy, application and orientation under the Moral Sensitivity Scale is statistically significant $(p<0,05)$. The state hospital nurses' scores from the sub-dimensions of autonomy, application and orientation are higher than the private hospital nurses.

The difference between the nurses' scores from the sub-dimension of orientation is statistically significant based on their professional seniority $(\mathrm{p}<0,05)$. Nurses with 5-year and less professional seniority have lower scores from the sub-dimension of orientation than the nurses with 11-year and more professional seniority. 
The scores of nurses, who worked 5-year and less at the hospital, from the Moral Sensitivity Scale in general and the sub-dimension of autonomy, benefit, application and orientation are significantly lower than the nurses with 6-10 year and 11-year and more experience at the hospital.

Based on the term of employment, the difference in the scores of nurses from the sub-dimensions of integrated approach and conflict under the Moral Sensitivity Scale is not statistically significant $(p>0,05)$. Although the scores of nurses that worked at the hospital for 5 years and lessfrom the sub-dimensions of integrated approach and conflict are less than other nurses, this difference is not significant.The difference between the scores of nurses from the Moral Sensitivity Scale in general and the subdimensions of autonomy, benefit, application and orientation is statistically significant $(p<0,05)$. The difference between the scores of nurses with monthly 1-3 night shifts from the Moral Sensitivity Scale in general and the subdimensions of autonomy, application and orientation is lower than the nurses with monthly 4-6 night shifts. Additionally, the scores of nurses with monthly 4-6 night shifts from the subdimension of benefit are higher than the nurses with monthly 7-9 night shifts.

Based on the monthly night shifts, the difference between the nurses' scores from the sub-dimensions of integrated approach and conflict is not statistically significant ( $p>0,05)$.

\section{CONCLUSION AND RECOMMENDATIONS}

Based on the outcomes, the majority of nurses encounter with ethical problems at their departments. While $50.86 \%$ of them solve such problems around $20 \%$ cannot, which is considered to be a high rate. The study by Bay1k(1995: 21) analysed a study by BancetandSullivan on the nurse managers and identified that $65 \%$ of the nurse managers face with unethical dilemma.The author gave the study by Ulrich et.al(2007)as an example and emphasized that around $40 \%$ of nurses feel weakness and pressure regarding ethical matters, around $50 \%$ of nurses feel disappointment and exhaustion when they cannot solve ethical issues, and 39\% do not have any organisational resource and processes that would help them in ethical problems. 
In terms of application principle, the state hospital nurses consider the decision to act and ethical dimension in practice more, and with regard to the orientation principles, the state hospital healthcare professionals show more care on their actions, which may affect their patient relationship, and the state hospital nurses have higher moral sensitivity than private hospital nurses. This situation is reflected with the fact that the longer employment terms of nurses at hospitals and higher number of nurses with professional experience positively affect the moral sensitivity results. Additionally, personalities and professional experience are also considered to affect the results respectively.

\section{Based on the professional} seniority of nurses, the difference between the nurses' scores from the subdimension of orientation is statistically significant $(p<0,05)$. The scores of nurses with 5-year and less professional seniority from the sub-dimension of orientation are lower than the nurses with 11 years and more professional seniority. In consideration with results, the nurses with 11 years and more professional seniority are more careful in their actions that may affect their relationship with patients and show more care accordingly. The results are also interpreted that professional experience increases the moral sensitivity. The study byKahriman İ,YeşilçiçekÇalıkK. (2017) reached to similar results with our study. The moral sensitivity of nurses with 1-10 year of employment is higher in the subdimensions of autonomy, benefit, integrated approach, conflict and orientation than the nurses with 11 years and more of employment. This result is interpreted in the way that the nurses with less professional experience may have encountered with less ethical conflicts or other members in healthcare team particularly doctors may have got more responsibility.

The study by Filizözet.al (2015) conducted on the state hospital nurses in Sivas city identified that nurses have medium-level of moral sensitivity. The study by Aksu and Akyol (2011) conducted in İzmir concluded that nurses have mid-level of moral sensitivity. Other literature studies also showed that the nurses have medium level of moral sensitivity (Başaket.al, 2010; Daşbilek, 2016;

Dikmen, 2013; TazegünandÇelebioğlu, 2016). On the other hand, there are some studies that identified high level of moral sensitivity 
among the nurses (DalcalıandŞendir, 2016; Tosun, 2005). The difference in the outcomes of various researches may have occurred since such studies were conducted with the nurses from different clinics and regions and the nurses may have ethical problems from different levels based on their services and they have the possibility to encounter with various cases.

\section{5.}

\section{RECOMMENDATIONS}

Pursuant to the results of this study, newly recruited nurses should be provided with trainings, which would enhance their awareness on ethics and moral sensitivity. Such trainings should be planned in accordance with their experience in the identification of ethical problems and proposal of solutions.

Private hospital nurses should be more careful towards the autonomy principle; hence, the related committees should be established that would work in planning, and in-service training should be provided accordingly.

$$
\text { It is also possible to }
$$

recommend that the numbers of monthly night shifts among nurses should be planned more carefully.

Moreover, the future studies should be conducted to reflect the need of ethics committees so that the studies would cover bigger groups with the other members of healthcare teams in order to identify the different variables affecting the moral sensitivities of nurses.

Hospital managements should put more interest into ethical matters, start working on such matters respectively and take the necessary measures, which would protect healthcare workers as well as patients from facing with ethical problems. Lastly, more solutions should be investigated accordingly.

\section{References}

Aksu, T., \& Akyol, A. (2011). İzmir'dekihemşirelerinetikduyarlılıkları nınincelenmesi.

TürkiyeKlinikleri Journal of Medical Ethics-Law and History, 19, 16-24

Ali Reza Salar, SadeghZare and EbrahimSharifzadeh, (2016). The Survey of NursingStudents' Ethical Sensitivity Salar et al., Biology and Medicine (Aligarh), 8:5 
Aydin

İp.

YönetselmeslekiveÖrgütseletik. Ankara:

PegemYayıncılık 2012.

Başak, T., Uzun, Ş., \& Arslan, F. (2010).Yoğunbakımhemşirelerininetikdu yarlıliklarının

incelenmesi.Gülhane Tıp Dergisi, 52, 7681.

Bay1k,

A.

"HemşirelikEğitimindeEtikKonusununÖ ğretimi”, HemşirelikBülteni 9/37, 19-30. Çobanoğlu, N.

Bilimpolitikalarınınyayınetiğineyansıma ları. SağglıBilimlerinde

SüreliYayıncılık. Yı1maz, O. (Ed.),

Ankara: TÜBİTAK, 60-69.

Dalcalı, BK., \&Şendir, M. (2016). Hemşirelerinkişiseldeğerleriileetikduyarl 1likları

arasındakiilişkininbelirlenmesi. Florence Nightingale HemşirelikDergisi, 24, 1-9.

DikmenYurdanur

YoğunBakımHemşirelerindeEtikDuyarlı lığınİncelenmesi,

CumhuriyetHemşirelikDergisi.

Filizöz, B., Așc1, A., Mesci, G., \&Bağcivan, E. (2015).

Hemşirelerdeetikduyarlılık: Sivas ili merkezkamuhastanelerindebiraraştırma. İşAhlak1Dergisi, 8, 47-66.

Fry S.( 2000). ICN, Internetional Council of Nurses, (Çevirieditörü). Erzurum: BakanlarMatbaac1lık,: 185-193.

Halstead J. Taylor MJ. Learning and teaching about values: a review of recent research.

Cambridge Journal of Education, 2000; 30:2 169-202.

Kahriman, İ. veYeşilçiçekÇalık K. (2017). Klinik Hemşirelerin Etik Duyarlılığ1, Gümüşhane Üniversitesi Sağlık Bilimleri Dergisi GÜSBD 2017; 6(3): 111 - 121, AraştırmaMakalesi.

Kim YS, Park JW, Son YJ. A Longitudinal Study on the Development of Moral Judgement inKorean Nursing Students. Nursing Ethics, 2004; 11:3 254-265.

O'Keefe, M. H. (2001). Nursing practice and the low: Avoiding malpractice and other legal risks, Philadelphia: F. A. Davis. Özcan M, Akpınar A, Ergin AB. Personal and professional values grading among midwiferystudents. Nurse Ethics, 2012; 19:3 399-407.

Öztürk H, Hintistan S, Kasım S veCandaş, B. (2009).

"YoğunBakımÜnitelerindeHekimve

HemşirelerinEtikDuyarlılığı".

YoğunBakımHemşireliğiDergisi, 13(2):77-84. 
Pekcan, H.S. (2007). Yalova İli veÇevresindeGörevYapanHekimlerinve HemşirelerinEtik

Duyarl1lıklar". Marmara

ÜniversitesiSağlıkBilimleriEnstitüsü, YüksekLisansTezi,

İstanbul.

Redman BK, Fry S. Nurses' ethical conflicts: what is really known about them, NursingEthics, 2000; 7:4 360-366.

Quinn, C.A. \&Smith, M.D. (1987). The

Professional Commitment: Issues and ethics in nursing, Philadelphia: Saunders Tosun,

H.(2005)SağlıkBakımıUygulamalarında

DeneyimlenenEtikİkilemlereKarş1

HekimveHemşirelerinEtikDuyarlılıkları

nınBelirlenmesi.YayınlanmamışDoktora

Tezi,

İstanbul Üniversitesi, İstanbul

ÜniversitesiSağlıkBilimleriEnstitüsü.

Danışman: Prof.Dr.

KameryaBabadağ,

İstanbul.https://tez.yok.gov.

tr/UlusalTezMerkezi/

adresindenedinilmiştir.

Lützén K, Blom T, Ewalds-Kvist B,

Winch S (2010) Moral stress, moral climate and moralsensitivity among psychiatric professionals. Nurs Ethics 17: 213-224.
Jahantigh M, Arbabisarjou A, Zare S, Shahrakipour M, Ghoreishinia G (2015) Hospital'sethical climate and nurse's desired ethical climate in Ali-ebnAbitaleb and Khatam-al-Anbia hospital of Zahedan (2015). Der Pharm Lett 7: 427-431.

Miandoab NY, Arbabisarjou A, Zare S, Shahrakipour M, Bradang N (2015) Operating room staff attitude toward the ethical climate of educational hospitals. Der Pharm Lett 7: 122-125.

Sar1, D. ve ark. (2017) AcilServisHemşirelerininEtikDuyarlılık1 arınınİncelenmesi. Dokuz EylülÜniversitesiHemşirelikFakültesiEle ktronikDergisi

Schroeter K (1999) Ethical perception and resulting action in perioperative nurses. AORN J 69: 991-1002.

Ulrich C, O'Donnell P, Taylor C et al. (2007). Ethical climate, ethics stress, and the job satisfaction of nurses and social workers in the united states, Social Science \& Medicine 65:1708-1719 